\title{
単相突発短絡試験による界磁相互漏れリアクタンスの推定と 乥の影響
}

\begin{tabular}{|c|c|c|c|c|}
\hline 正 員 & 平松 大典* & 正 員 & 小柳 & 薫 ${ }^{* *}$ \\
\hline 員 & 平山開一郎* & 正 員 & 上村 & 洋市* \\
\hline 員 & 正* & 正 員 & 高畠 & 幹生* \\
\hline & 利幸*** & 正 員 & 荒 & 逢裕**** \\
\hline
\end{tabular}

Estimation of Field Mutual Leakage Reactance by Line-to-Line Sudden Short Circuit

Test and Effect of Reactance

Daisuke Hiramatsu*, Member, Kaoru Koyanagi**, Member, Kaiichirou Hirayama*, Member, Yoichi Uemura*, Member, Tadashi Tokumasu*, Member, Mikio Takabatake*, Member, Toshiyuki Satoh ${ }^{* * *}$, Non-member, Takahiro Ara ${ }^{* * *}$, Member

This paper describes the effect of mutual leakage reactance in rotor circuit (Canay reactance) on analysis of medium capacity generator transient and dynamic behavior. The authors proposed the decision method of field mutual leakage reactance, and analyzed sudden short circuit and voltage dip on sudden load application by simulations using the electromagnetic transients program (ATP-EMTP) and compared the results with the experimental data.

キーワード：発電機, 単相突発短絡, 負荷投入, 界磁相互漏れリアクタンス, EMTP

Keywords: generator, line-to-line sudden short circuit, sudden application of a load, field mutual leakage reactance, EMTP

\section{1. まえがき}

従来から同期機の等価回路モデルとして図 1 に示した Park モデル (a) を用いて過渡現象を解析することが一般的 である ${ }^{(1)}$ 。すなわち $\mathrm{d}$ 軸に対して, 3 個の巻線 (電機子巻 線・界磁巻線・制動巻線) 全てに鎖交する主磁束と各巻線 の漏れ磁束をべースにしていた。

* (株) 東芝 京浜事業所

(筆頭者) † 230-0045 横浜市鶴見区末広町 2-4

Toshiba Corporation

2-4, Suehiro-cho, Tsurumi-ku, Yokohama 230-0045

** (株) テプコシステムズ

† 105-0004 東京都港区新橋 6-19-15

Tepco Systems Corporation

6-19-15, Shimbashi, Minato-ku, Tokyo 105-0004

*** 北芝電機 (株)

干 960-1292 福島市松川町字天王原 9

Kitashiba Electric Corporation

9, Matsukawa-cho, Aza Tennoubara, Fukushima 960-1292

雇用 能力開発機構 職業能力開発総合大学校

₹ 229-1196 相模原市橋本台 4-1-1

Employment and Human Resources Development

Organization of Japan, Polytechnic University

4-1-1, Hashimotodai, Sagamihara 229-1196
これに対し，三相突発短絡時の界磁電流特性について Park モデル (a) による解析值と実測值とに差が有ることが報告 されている。この現象について, 界磁巻線・制動巻線のみ を取り囲む磁束に対応する界磁相互漏れリアクタンス $\left(x_{c}\right.$ : Canay リアクタンスとも呼ばれている) を考慮した等価回

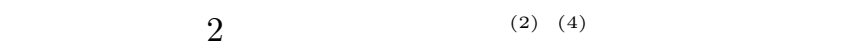
断時の過渡特性等を中心に, 従来モデルとの違いについて の検討を行ってきた ${ }^{(5)(6)}$ 。

界磁相互漏れリアクタンスは三相突発短絡時の界磁電流 波形から求める方法が一般的で有る。この方法は大容量機 では比較的容易であるが, 中小容量機では電機子時定数が 小さく過渡直流分の減衰が速いので測定が難しい面がある。
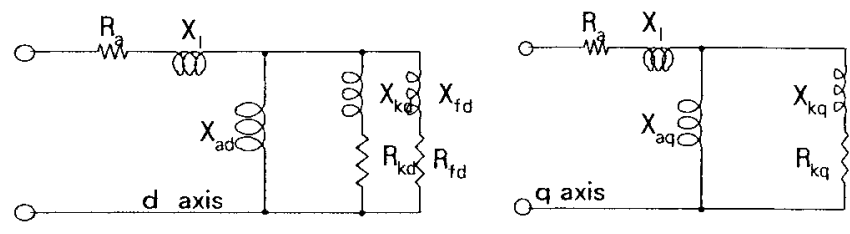

図 1 Park モデル (a)

Fig. 1. Park model (a). 


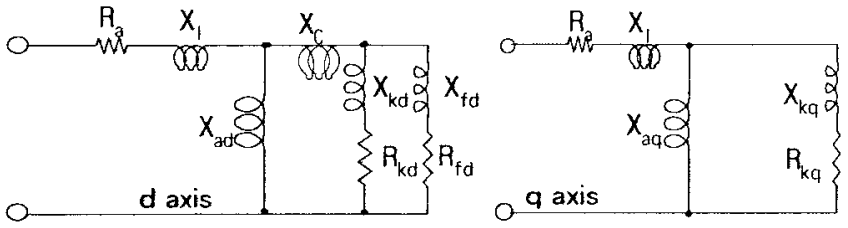

図 2 界磁相互漏れリアクタンスを考慮したモデル

Fig. 2. Considered field mutual leakage reactance model.

弚こで今回，筆者等は，界磁相互漏れリアクタンスの推定 方法として単相突発短絡試験を利用する方法を提案すると ともに, 中小容量発電機システムの応答性評価に採用され る負荷投入特性に対する界磁相互漏れリアクタンスの影響 について検討したので報告する。

\section{2. 三相突発短絡時の界磁電流について}

〈2. 1〉 解析モデルと基本式 今回の解析て採用した同 期機モデルの界磁部分を図 3 に示す。ここで(1)大容量発電 機モデルとして 48P-15750kVA-11000V-50Hz(2)中容量発 電機モデルとして $6 \mathrm{P}-400 \mathrm{kVA}-3300 \mathrm{~V}-50 \mathrm{~Hz}$ (いずれも突 極機) を使用した。発電機は無限大母線に接続されている 系統モデル , 線路のインピーダンスは , ほぼゼロ $\left(10^{-6} \Omega\right)$ とした。励磁方式はブラシレス交流励磁方式である。なお 48P-15750kVA のリアクタンス・時定数を付録に示した。

〈2. 2〉 三相突発短絡時の界磁特性と従来モデル 図 4 に 48P-15750kVA 突極形発電機の三相突発短絡時の界磁特 性実測波形を示す。

三相突発短絡時の界磁電流は (1) 式で与えられる ${ }^{(2)}(7) 。$

$$
\begin{aligned}
i_{f 3 p h a s e}= & i_{f o}+i_{f o} \frac{x_{d}-x_{d}^{\prime}}{x_{d}^{\prime}} \\
& \times\left\{e^{-t / T_{d}^{\prime}}-\left(1-\frac{T_{k d}}{T_{d}^{\prime \prime}}\right) e^{-t / T_{d}^{\prime \prime}}\right. \\
& \left.-\frac{T_{k d}}{T_{d}^{\prime \prime}} e^{-t / T_{a}} \cos 2 \pi f t\right\} \ldots \ldots \ldots
\end{aligned}
$$

ここで $i_{f o}$ : 短絡前界磁電流, $T_{k d}=x_{k d} / 2 \pi f R_{k d}: \mathrm{d}$ 軸ダ ンパー回路時定数，他は 2 軸理論の一般的なリアクタンス・ 時定数である。

図 4 の三相突発短絡試験の電機子電流波形から得られた リアクタンス・時定数 $x_{d}, x_{d}^{\prime}, x_{d}^{\prime \prime}, T_{d}^{\prime}, T_{d}^{\prime \prime}$ を用いて Park モデル (a) によりシミュレーションした界磁電流波形を図 5 に示す。実測値と (1) 式の計算値とは差がある。簡易的な (1) 式のみならず, 連続系シミュレーション言語による解 析, EMTP $(\mathrm{ATP})$ による解析結果も同樣な差が見られた。

〈2.3〉界磁相互漏れリアクタンスの推定 以上, 従来 は電機子端子から見た特性をベースにPark モデル (a) の 各リアクタンス・時定数を算定しているため, 界磁電流特 性の実測値と差を生じていると考えられる。光こで, 三相 突発短絡時の電機子端子から見た特性とともに，界磁電流 特性をもとに界磁相互漏れリアクタンスを算出し，光れを 考慮したPark モデル (b)（図 2) の適用を考える。

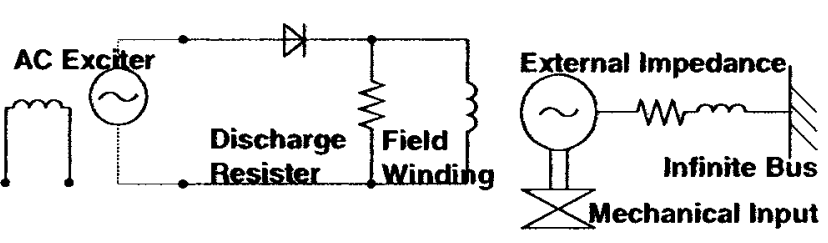

図 3 解析モデル

Fig. 3. Analysis model.

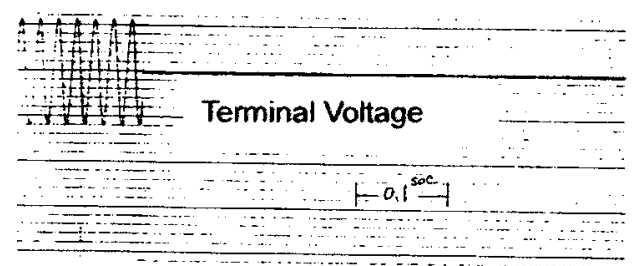

Field Current
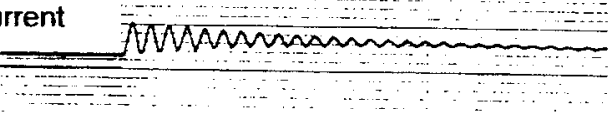

図 4 48P-15750kVA 三相突発短絡時の界磁特性

Fig. 4. Field characteristics of 3-phase sudden short circuit 48P-15750kVA.

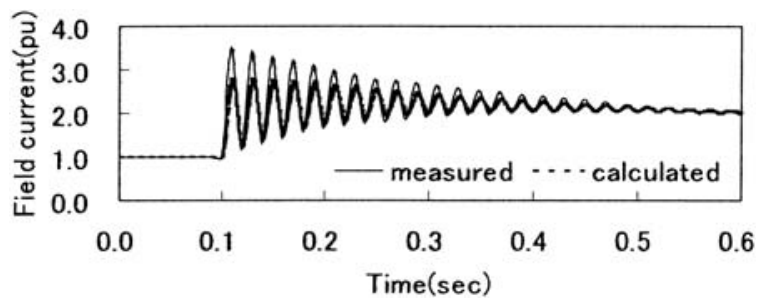

図 5 三相突発短絡 (無負荷時) 界磁電流

Fig. 5. Field current during three-phase sudden short circuit at no load.

界磁相互漏れリアクタンス $x_{c}$ を考慮した Park モデル (b) (図 2) において三相突発短絡から得られる定数 $x_{d}$, $x_{d}^{\prime}, x_{d}^{\prime \prime}, T_{d}^{\prime}, T_{d}^{\prime \prime}$ と各リアクタンスの関係は次の樣になる。

$$
\begin{aligned}
& x_{d}=x_{l}+x_{a d} \\
& x_{d}^{\prime}=x_{l}+\frac{x_{a d}\left(x_{f d}+x_{c}\right)}{x_{a d}+x_{f d}+x_{c}} \\
& x_{d}^{\prime \prime}=x_{l} \\
& +\frac{x_{a d} x_{f d} x_{c}+x_{a d} x_{c} x_{k d}+x_{a d} x_{f d} x_{k d}}{x_{a d} x_{f d}+x_{a d} x_{k d}+x_{f d} x_{k d}+x_{c} x_{k d}+x_{c} x_{f d}} \\
& \text {.............. (4) } \\
& T d^{\prime}=\frac{1}{\omega R_{f d}}\left(x_{f d}+x_{c}+\frac{x_{a d} x_{l}}{x_{a d}+x_{l}}\right) . \\
& T d^{\prime \prime}=\frac{1}{\omega R_{k d}} \\
& \times\left(x_{k d}+\frac{x_{a d} x_{c} x_{f d}+x_{a d} x_{f d} x_{l}+x_{c} x_{f d} x_{l}}{x_{a d} x_{f d}+x_{f d} x_{l}+x_{c} x_{a d}+x_{c} x_{l}+x_{a d} x_{l}}\right) \\
& \text {.............. }
\end{aligned}
$$

従来のPark モデル $(\mathrm{a})$ では $x_{c}=0$ であり，変数が $1 つ$ 


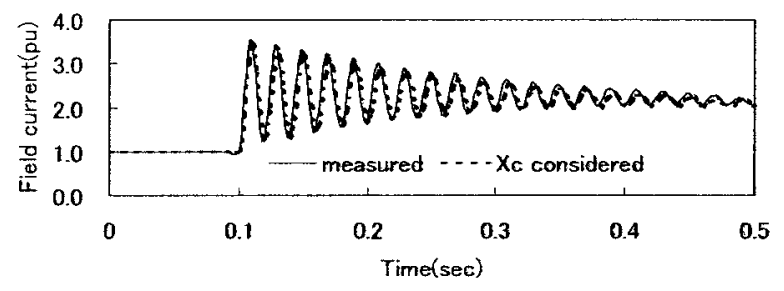

図 6 三相突発短絡時界磁電流解析值 $\left(x_{c}\right.$ 考慮)

Fig. 6. Field current during three-phase sudden short circuit at no load (considering $x_{c}$ ).

減ることから各リアクタンス成分を求めることができる†。 しかし界磁相互漏れリアクタンス $x_{c}$ を考慮すると, 各リア クタンス成分の決定にはさらに条件が必要である。

〈2. 4〉 三相突発短絡試験による界磁相互漏れリアクタ ンスの推定 界磁相互漏れリアクタンス $x_{c}$ 推定にあた り，三相突発短絡時の界磁電流特性を使用する方法が一般 的である ${ }^{(2)}{ }^{(3)}$ 。三相突発短絡時の界磁電流 (1) 式の直流分 を(7) 式に記す。

$$
\begin{aligned}
& i_{f 3 \text { phase } D C} \\
& =i_{f o}+i_{f o} \frac{x_{d}-x_{d}^{\prime}}{x_{d}^{\prime}}\left\{e^{-t / T_{d}^{\prime}}-\left(1-\frac{T_{k d}}{T_{d}^{\prime \prime}}\right) e^{-t / T_{d}^{\prime \prime}}\right\}
\end{aligned}
$$

ここで界磁電流実測波形に包絡線を描く事により短絡瞬 時の直流分 $i_{f 3 D C 0}$ を求める事ができる。短絡前の界磁電 流を $i_{f 30}$ とすると次の関係式が成立する ${ }^{(8)}$ 。

$$
\begin{aligned}
& i_{f 3 D C 0}=i_{f 30}+K_{3} i_{f 30} \cdots \\
& K_{3}=\frac{x_{d}-x_{d}^{\prime}}{x_{d}^{\prime}} \frac{T_{k d}}{T_{d}^{\prime \prime}} \cdots \cdots \\
& T_{k d}=\frac{x_{k d}}{2 \pi f R_{k d}} \cdots \cdots \cdots
\end{aligned}
$$

(8)，(9) 式から $T_{k d}$ を求め,,$(2) \sim(6)$ 式と (10) 式を連立 させて解く事により図 2 の各リアクタンス成分を求める事 ができる。以上の手順により，モデル機の場合，界磁漏れ リアクタンス $x_{c}(=-0.112)$ を算出した。この $x_{c}$ を用い てシミュレーションを行った結果を図 6 に示す。結果は実 測とよく一致している。

3. 単相突発短絡試験による界磁相互漏れリアクタ ンスの推定

〈3. 1〉 中容量発電機の三相突発短絡時の界磁電流特性 中容量発電機モデル $6 \mathrm{P}-400 \mathrm{kVA} の$ 三相突発短絡時の界 磁電流実測值を図 7 に示す。

図 7 の樣に中容量発電機では電機子側抵抗分が大きく過 渡直流分の減衰が速く, 前節で述べた界磁電流の包絡線を 利用し，界磁相互漏れリアクタンスを推定する事は容易で はない。

そこで以下，筆者等は新たに電機子抵抗分が大きい場合

†ここで $x_{l}($ 電機子漏れリアクタンス $)$ は実測か難しいことから本論 文では設計值を使用することとした。

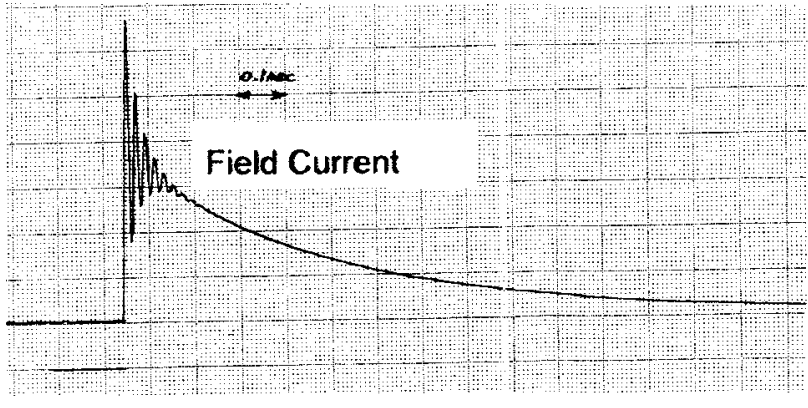

図 7 6P-400kVA 三相突発短絡時の界磁電流 実測値

Fig. 7. Field current of 3-phase sudden short circuit 6P-400kVA.

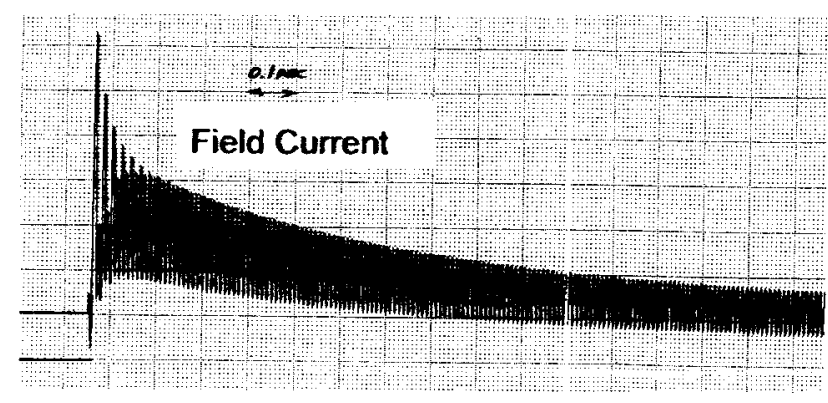

図 $86 \mathrm{P}-400 \mathrm{kVA}$ 単相突発短絡時の界磁電流 実測値

Fig. 8. Field current of Line-to-Line sudden short circuit $6 \mathrm{P}-400 \mathrm{kVA}$.

でも推定精度の落ちない，三相突発短絡試験に替わる界磁 相互漏れリアクタンス推定法を提案する。

〈3.2〉 単相突発短絡試験による推定法の提案 単相 (線間) 突発短絡試験は逆相リアクタンスの測定に適用され る ${ }^{(4)}$ が, 三相突発短絡試験ほど一般的ではない。図 8 に $6 \mathrm{P}-400 \mathrm{kVA}$ 単相突発短絡時の界磁電流実測値を示す。三 相突発短絡時と比較し, 電機子回路過渡直流分による基本 波成分の減衰は速いが, 2 倍の高調波分は継続している。

以下，筆者等が提案する単相突発短絡試験を用いて界磁 相互漏れリアクタンスを推定する 2 つの方法を紹介する。

単相突発短絡時の界磁電流は (11) 式で示される ${ }^{(7)}$ 。

$$
\begin{aligned}
& i_{f 1 \text { phase }} \\
& \quad=\left\{\left(\frac{x_{k d}}{x_{f d}+x_{k d}} \frac{x_{d}-x_{d}^{\prime \prime}}{x_{d}^{\prime \prime}+x_{2}}-\frac{x_{d}-x_{d}^{\prime}}{x_{d}^{\prime}+x_{2}}\right) e^{-t / T_{d(l-1)}^{\prime \prime}}\right. \\
& \quad+\frac{x_{d}-x_{d}^{\prime}}{x_{d}^{\prime}+x_{2}} e^{\left.-t / T_{d(l-1)}^{\prime}+1\right\} i_{f o}} \\
& \quad-\frac{x_{k d}}{x_{f d}+x_{k d}} \frac{x_{d}-x_{d}^{\prime \prime}}{x_{d}^{\prime \prime}+x_{2}}(1+b) \\
& \quad \times\{F(\cos 2 \theta-b \cos 4 \theta+\cdots) \\
& \left.\quad+\frac{x_{d}^{\prime \prime}+x_{2}}{x_{2}} e^{-t / T_{a}} \sin \alpha(\sin \theta-b \sin 3 \theta+\cdots)\right\} i_{f o}
\end{aligned}
$$




$$
\begin{aligned}
& \text { こニで } \\
& \qquad \begin{aligned}
F= & \left(1-\frac{x_{d}^{\prime \prime}+x_{2}}{x_{d}^{\prime}+x_{2}}\right) e^{-t / T_{d(l-1)}^{\prime \prime}} \\
& +\left(\frac{x_{d}^{\prime \prime}+x_{2}}{x_{d}^{\prime}+x_{2}}-\frac{x_{d}^{\prime \prime}+x_{2}}{x_{d}+x_{2}}\right) e^{-t / T_{d(l-1)}^{\prime}} \\
& +\frac{x_{d}^{\prime \prime}+x_{2}}{x_{d}+x_{2}}
\end{aligned} \\
& T_{d(l-1)}^{\prime \prime}=T_{d o}^{\prime \prime} \frac{x_{d}^{\prime \prime}+x_{2}}{x_{d}^{\prime}+x_{2}}, \quad T_{d(l-1)}^{\prime}=T_{d o}^{\prime} \frac{x_{d}^{\prime}+x_{2}}{x_{d}+x_{2}}
\end{aligned}
$$

また

$$
b=\frac{x_{2}-x_{d}^{\prime \prime}}{x_{2}+x_{d}^{\prime \prime}}, \quad \theta=2 \pi f t+\alpha
$$

$\alpha$ : 短絡時の位相(磁極軸の $\mathrm{a}$ 相磁化軸に対する進み角)

$$
\frac{x_{k d}}{x_{f d}+x_{k d}}
$$

: 界磁巻線と制動巻線の分流比である。

(a) 直流分からの推定 単相突発短絡直後の波形に 注目する。(7) 式と同樣に (11) 式から直流分を抽出すると (13) 式となる。 $x_{d}, x_{d}^{\prime}, x_{d}^{\prime \prime}, x_{2}, T_{d}^{\prime}, T_{d}^{\prime \prime}$ は電機子端子側 から見たリアクタンス・時定数であり, 界磁相互漏れリア クタンス考慮の有無にはよらない。界磁相互漏れリアクタ ンス $x_{c}$ 考慮の有無は (12) 式の分流比に反映される。

$$
\begin{aligned}
& i_{f 1 \text { phase } C} \\
& =\left\{\left(\frac{x_{k d}}{x_{f d}+x_{k d}} \frac{x_{d}-x_{d}^{\prime \prime}}{x_{d}^{\prime \prime}+x_{2}}-\frac{x_{d}-x_{d}^{\prime}}{x_{d}^{\prime}+x_{2}}\right)\right. \\
& \left.\quad \times e^{-t / T_{d(l-1)}^{\prime \prime}}+\frac{x_{d}-x_{d}^{\prime}}{x_{d}^{\prime}+x_{2}} e^{-t / T_{d(l-1)}^{\prime}}+1\right\} i_{f o}
\end{aligned}
$$

界磁電流実測值から，短絡瞬時の直流分 $i_{f 1 D C 0}$ を求める 事ができる。ここで短絡前の界磁電流を $i_{f 10}$ とすると次の 樣になる。

$$
\begin{aligned}
& i_{f 1 D C 0}=i_{f 10}+K_{1 D C} i_{f 10} \cdots \\
& K_{1 D C}=\frac{x_{k d}}{x_{f d}+x_{k d}} \frac{x_{d}-x_{d}^{\prime \prime}}{x_{d}^{\prime \prime}+x_{2}} .
\end{aligned}
$$

実測結果から (15) 式の分流比に相当する値を求め, $(2)$ (6) 式と連立させて解くことにより, 界磁相互漏れリアク タンス $x_{c}$ を含む全リアクタンスと抵抗を算定する事がで きる。

(b) 交流分からの推定 次に単相突発短絡実施後の 永久短絡時に注目する。

時定数による減衰を考慮すると永久短絡時の (11) 式の界 磁電流交流分は (16) 式となる。

$$
i_{f 1 p h a s e A C}=\frac{x_{k d}}{x_{f d}+x_{k d}} \frac{x_{d}-x_{d}^{\prime \prime}}{x_{d}+x_{2}} \cos 2 \theta \times i_{f o}
$$

$$
\text { ただし，ここで }|b|=\left|\frac{x_{2}-x_{d}^{\prime \prime}}{x_{2}+x_{d}^{\prime \prime}}\right| \ll 1 \text { とした 。 }
$$

( a )項で述へた直流分による推定と同樣に $x_{d}, x_{d}^{\prime}, x_{d}^{\prime \prime}, x_{2}$, $T_{d}^{\prime}, T_{d}^{\prime \prime}$ は電機子端子側から見たリアクタンス，時定数で あり, 界磁相互漏れリアクタンス考慮の有無にはよらない。 また 2 倍周波分の振幅を $K_{1 A C}$ とすると (17) 式となる。

$$
K_{1 A C}=\frac{x_{k d}}{x_{f d}+x_{k d}} \frac{x_{d}-x_{d}^{\prime \prime}}{x_{d}+x_{2}} .
$$

(2) (6) 式と (17) 式を連立させて解く事により。界磁相互 漏れリアクタンス $x_{c}$ を含む全リアクタンスと抵抗を算定 する事ができる。

\section{4. 提案手法の検証}

前章で単相突発短絡時の界磁電流から界磁相互漏れリア クタンスを推定する方法を提案した。ここで, 本提案手法 の妥当性を確認するため, EMTP シミュレーション及び実 機測定データにより，界磁相互漏れリアクタンスを推定し てみた。

\section{〈4 1〉 EMTP シミュレーションによる検証}

( a ） 直流分からの推定 モデル機 48P-15750kVA は 图 4 の三相突発短絡試験の結果から各リアクタンス及び $x_{c}$ を求めることができた。この定数を用いて EMTP による 単相突発短絡シミュレーションを行った。

単相突発短絡では短絡発生時のタイミング (位相) によ り電機子電流, 界磁電流波形が異なってくる。図 9 図 12 に短絡発生時のタイミングを電気角 90 度の位相差で変化 させた 2 例 (Case1: 図 9, 図 11 Case2: 図 10, 図 12) を示す。

图 13 にCase1，2の界磁電流について直流分を求めた結 果を示す。図 11 , 図 12 の樣に単相短絡時の波形は短絡時 の位相により全く異なるが，基本波及び 2 倍の高周波分を 除いた直流分の挙動は同一であることがわかる。

実測の場合，短絡時の位相を制御する事は困難であるが， 短絡時の位相によらず界磁電流直流分が一定で有る事から 一意的に上記推定法が適用できる。本例では, 界磁相互漏

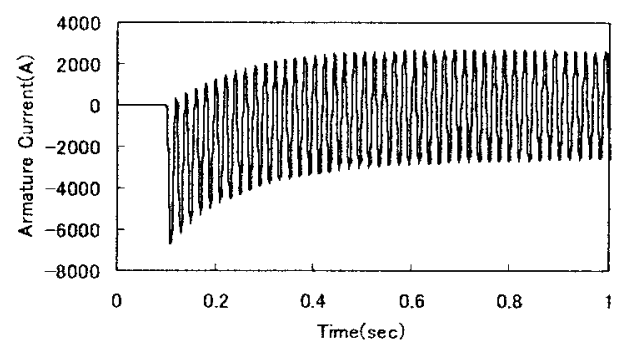

図 $948 \mathrm{P}-15750 \mathrm{kVA}$ 単相突発短絡時の電機子電流 (Case1)

Fig. 9. Simulation of armature current during Line-to-Line sudden short circuit 48P-15750kVA (Case1).

\footnotetext{
†これが成立する条件については付録に示す。
} 


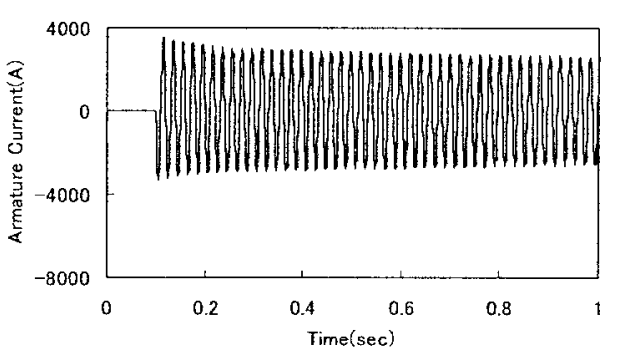

図 $1048 \mathrm{P}-15750 \mathrm{kVA}$ 単相突発短絡時の電機子電流 (Case2)

Fig. 10. Simulation of armature current during Line-to-Line sudden short circuit 48P-15750kVA (Case2).

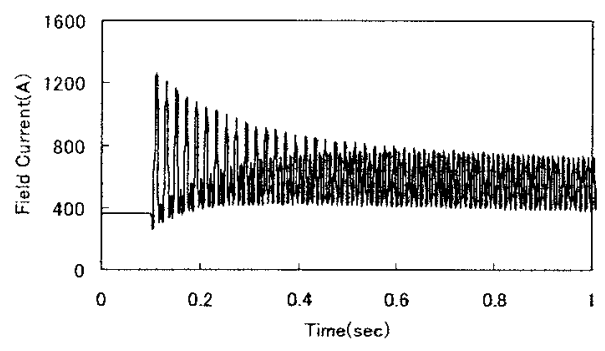

図 $1148 \mathrm{P}-15750 \mathrm{kVA}$ 単相突発短絡時の界磁電流 (Case1)

Fig. 11. Simulation of field current during Line-toLine sudden short circuit 48P-15750kVA (Case1).

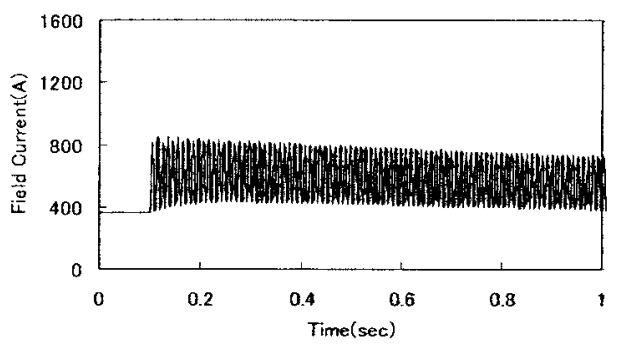

図 12 48P-15750kVA 単相突発短絡時の界磁電流 (Case2)

Fig. 12. Simulation of field current during Line-toLine sudden short circuit 48P-15750kVA (Case2).

れリアクタンスとして $x_{c}(=-0.115)$ が得られた。

(b) 交流分からの推定 図 9〜图 12 は短絡発生か ら 1 秒までの波形を示している。Case1，2 について減衰 終了後の 9.5 秒から 10 秒までの界磁電流振動波形を図 14 に示す。

短絡時の位相により短絡瞬時の電機子電流及び界磁電流 の波形は異なっているが，減衰分が終了した後の交流分振 幅は Case1，2 で同等である事がわかる。直流分と同樣，短 絡時の位相によらず界磁電流交流分振幅が一定で有る事か ら一意的に上記推定法が適用できる。本例では，界磁相互 漏れリアクタンスとして $x_{c}(=-0.117)$ が得られた。

以上 EMTP によるシミュレーション結果から各方法に よって求めた界磁相互漏れリアクタンスは以下の樣に，ほ ぼ同等となり提案手法を検証する事ができた。

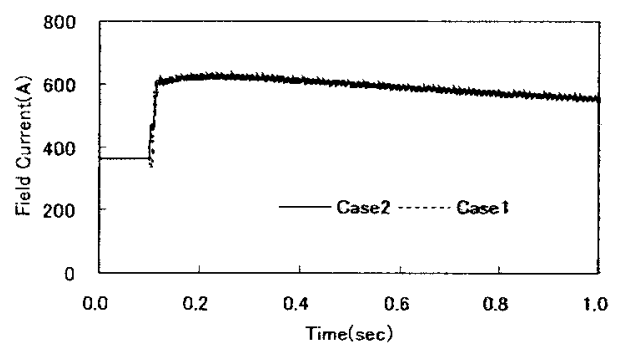

図 13 48P-15750kVA 単相突発短絡時界磁電流 直流分

Fig. 13. Simulation of field current DC component during Line-to-Line sudden short circuit 48P15750kVA (Case1, 2).

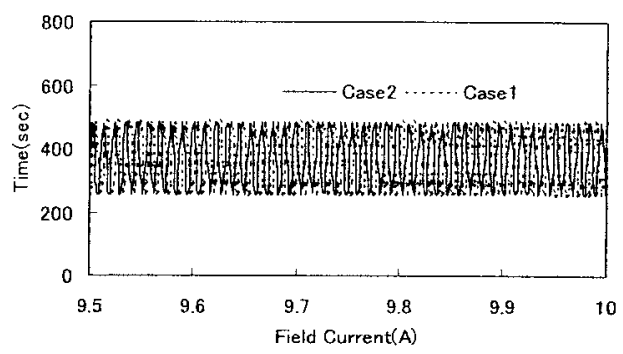

図 14 48P-15750kVA 単相突発短絡時界磁電流 振動分

Fig. 14. Simulation of field current AC component during Line-to-Line sudden short circuit 48P15750kVA (Case1, 2).

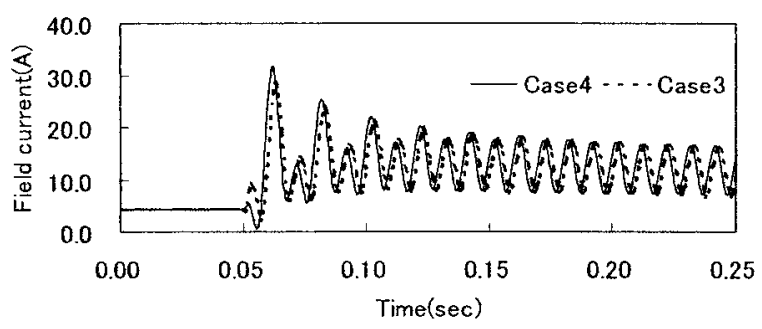

图 $156 \mathrm{P}-400 \mathrm{kVA}$ 単相突発短絡時の界磁電流

Fig. 15. Field current of Line-to-Line sudden short circuit $6 \mathrm{P}-400 \mathrm{kVA}$.

(1) 三相突発短絡時の界磁電流より $\cdots \cdots \cdots x_{c}=-0.112$

(2) 単相突発短絡時の界磁電流直流分より $\cdots x_{c}=-0.115$

(3) 単相突発短絡時の界磁電流交流分より $\cdots x_{c}=-0.117$

〈4:2〉実機による検証 次に実機による提案手法の検 証結果を報告する。図 7 に示した樣に $6 \mathrm{P}-400 \mathrm{kVA}$ では三 相突発短絡時の界磁電流は減衰が速く，この波形から界磁 相互漏れリアクタンスを推定する事は難しい。前節と同樣 に, 単相突発短絡試験結果から界磁相互漏れリアクタンス を推定する。短絡発生のタイミングを変化させた 2 ケース (case3，4) の界磁電流実測波形を図 15 に示す。

図 16 に Case3，4 における単相突発短絡直後の界磁電 流直流分を示す。短絡時のタイミングによらず，直流分は 同等である事がわかる。これより $x_{c}=-0.082$ を得る。ま た減衰終了後の界磁電流交流分から $x_{c}=-0.085$ を得る。 


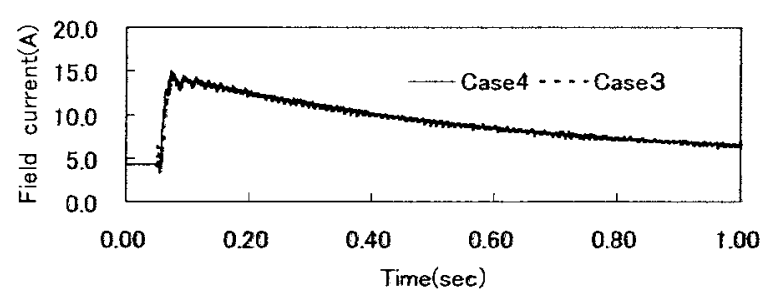

図 16 6P-400kVA 単相突発短絡時界磁電流直流分 Fig. 16. Field current DC component during Lineto-Line sudden short circuit 6P-400kVA.

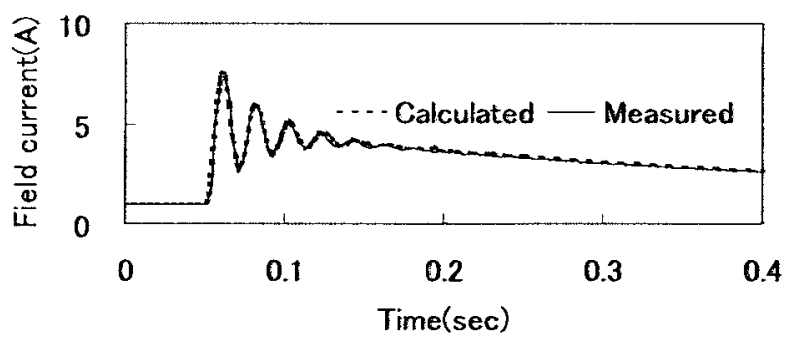

図 $176 \mathrm{P}-400 \mathrm{kVA}$ 三相突発短絡時の界磁特性

Fig. 17. Field characteristics of during 3-phase sudden short circuit $6 \mathrm{P}-400 \mathrm{kVA}$.

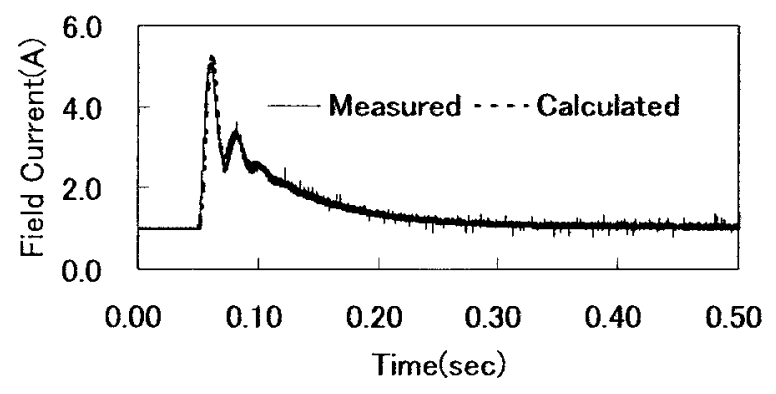

図 $184 \mathrm{P}-10 \mathrm{kVA}$ 三相突発短絡時の界磁特性

Fig. 18. Field characteristics of during 3-phase sudden short circuit 4P-10kVA.

EMTP シミュレーション同樣 , 両方法による推定は , ほぼ 同等である。

次に得られた $x_{c}$ を用いて三相突発短絡時の界磁電流を シミュレーションした結果と実測値との比較を図 17 に示 す。ほぼ一致しており推定方法の妥当性が確認された。

また同樣な手法により $4 \mathrm{P}-10 \mathrm{kVA}$ 突極発電機でも単相突 発短絡試験から得られた $x_{c}$ を用いて三相突発短絡シミュ レーションを行った結果を图 18 に示す。実測值とほぼ一 致した結果が得られ，三相突発短絡時の界磁電流基本波分 の減衰が大きい小容量機に対しても，本提案の推定が十分 に適用可能であることが確認された。

\section{5. 界磁相互漏れリアクタンスと負荷投入特性}

3 章で述べた樣に界磁相互漏れリアクタンスを考慮する ことは, (9) 式に示した界磁巻線と制動巻線の分流比に影 響する。乥こで筆者等は界磁相互漏れリアクタンスを考慮 した場合の界磁電流，端子電圧への影響を負荷遮断，PSS

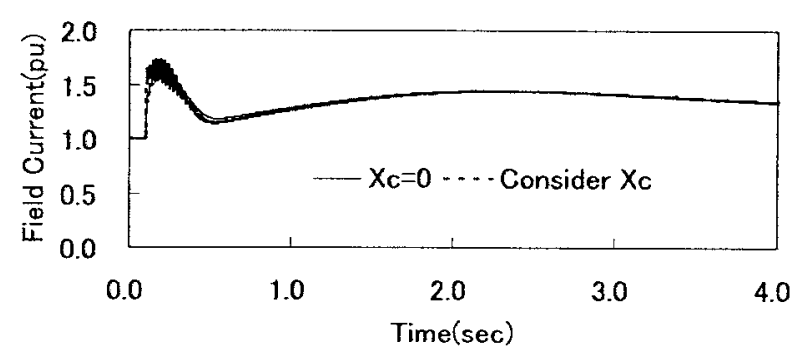

図 19 負荷投入時界磁電流解析值

Fig. 19. Simulation of generator field current during sudden application of a load.

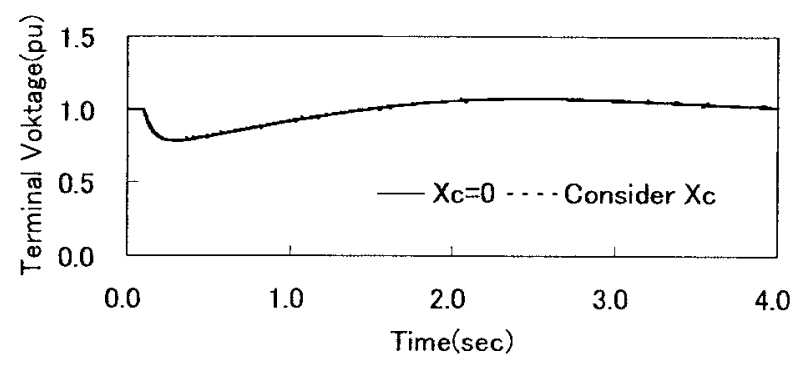

図 20 負荷投入時端子電圧解析値

Fig. 20. Simulation of generator terminal voltage during sudden application of a load.

効果について検討した結果を報告してきた ${ }^{(5)(6)}$ 。今回 , 中 容量発電機と励磁システムとの評価に広く用いられる負荷 投入特性について考えてみた。

4 章で得られた $x_{c}$ を用いて EMTP により $6 \mathrm{P}-400 \mathrm{kVA}$ 発電機が $4 \mathrm{P}-50 \mathrm{~kW}$ (始動 $\mathrm{kVA}: 370 \mathrm{kVA}$ ) 誘導電動機を 始動した場合のシミュレーションを行った。なお励磁は中 容量で広く用いられる自励複巻方式とした。

図 19 , 図 20 に界磁相互漏杪アクタンス $x_{c}$ 考慮の有 無による界磁電流, 端子電圧 (実効値) の変化を示す。

図 20 から分かるように, 端子電圧は $x_{c}$ 考慮の有無にか かわらず, 同樣な結果である。また，図 19 の界磁電流には 負荷投入直後に若干の差異が見られる。今回のモデル機で は $x_{c}<0$ であり，負荷投入にともない界磁回路に分流す る割合が $x_{c}=0$ の場合と比較し変化する。図 19 の投入直 後の差はこれによるものと考えられる。一方，端子電圧は 電機子側から見た諸定数 $x_{d}, x_{d}^{\prime}, x_{d}^{\prime \prime}, T_{d}^{\prime}, T_{d}^{\prime \prime}$ に依存し， AVR て制御されていることから, 負荷遮断時と同樣に界磁 相互漏れリアクタンスによる有意差がないと考えられる。

6. まとめ

発電機過渡時界磁電流特性に影響を与える界磁相互漏れ リアクタンスについて三相・単相突発短絡, 負荷投入の検 討を行い次の点が明らかになった。

・突発短絡試験実測值から，界磁電流の動きを考える場 合，回転子側のみに鎖交する磁束に対応する界磁相互 漏れリアクタンス (Canay のリアクタンス) を考慮し た方が実際の現象に近い波形となる。 
・界磁相互漏れリアクタンスの推定方法としては従来， 三相突発短絡時の界磁電流特性を用いる事が一般的で ある。しかし中小容量発電機では電機子側抵抗分が大 きく過渡直流分の減衰が速く, 界磁相互漏れリアクタ ンスを推定する事は容易ではない。关こで今回

(1) 単相突発短絡時の界磁電流直流分

(2) 単相突発短絡時の界磁電流交流分

を用いる方法を提案し，シミュレーション，実測デー タから妥当性を確認する事が出た。

・シミュレーションの結果から，負荷投入時の界磁電流， 端子電圧はAVR の制御に支配されるため, 負荷遮断 時と同樣に界磁相互漏れリアクタンス考慮の有無によ

る違いは顕著には現れにくいと考えられる。

今後,さらに非同期投入等の発電機過渡現象時における， 界磁相互漏れリアクタンスの界磁特性への影響について検 討を行う予定である。

(平成 15 年 6 月 23 日受付, 平成 15 年 8 月 21 日再受付)

\section{文献}

(1) R.H. Park: "Two Reaction Theory of Synchronous Machines", Trans. AIEE, Vol.48, p.716 (1929)

(2) B. Adkins: The General Theory of Electrical Machines, Chapman and Hall (1957)

(3) I.M. Canay: "Causes of Discrepancies on Calculation of Rotor Quantities and Exact Equivalent Diagrams of The Synchronous Machine", IEEE Trans. Power Apparatus Syst., Vol.PAS-88, No.7, p.1114 (1969)

(4) "Application technology of synchronous machine constants", IEE Japan Technical Report, No.798 (2000) (in Japanese) 「同期機諸定数の適用技術」, 電気学会技術報告, No.798 (2000)

( 5 ) D. Hiramatsu, K. Koyanagi, K. Hirayama, Y. Uemura, and T. Sato: "Analysis of Generator Load Rejection Phenomena influenced by the Rotor Leakage Reactance", National Convention Record IEE Japan, 6-031 (2003) (in Japanese) 平松大典・小柳 董・平山開一郎・上村洋市・佐藤利幸 :「発電機 過渡時における界磁漏れリアクタンス」, 平成 15 年電気学会全国大 会, 6-031 (2003)

(6) K. Koyanagi, D. Hiramatsu, K. Hirayama, and Y. Uemura: "A Study on PSS Effects Using a Genarator Model with Canay Reactance", National Convention Record IEE Japan, 6-032 (2003) (in Japanese)

小柳 薰・平松大典・平山開一郎・上村洋市: 「界磁漏れリアクタン スを考慮した発電機モデルに基づくPSS 効果の解析」, 平成 15 年 電気学会全国大会, 6-032 (2003)

(7) T. Igari: Theory of Electrical Machine, CORONA Publishing, CO., LTD. (1977) (in Japanese) 猪狩武尚：電気機械理論, コロナ社 (1977)

(8) Y. Takeda and B. Adkins: "Determination of synchronousmachine parameters allowing for unequal mutual inductance", Proc. IEE, Vol.121, No.12 (1974-12)

\section{付 録}

1. モデル機定格とリアクタンス・時定数

定格 : 48P-15750kVA-125min ${ }^{-1}-11000 \mathrm{~V}-50 \mathrm{~Hz}$
付表 1 モデル機 $\mathrm{d}$ 軸定数

app. Table 1. d-axis constants of model machine.

\begin{tabular}{c|c|c|c|c|c} 
& $\mathrm{X}_{\mathrm{c}=0}$ & $\begin{array}{c}\mathrm{X}_{\mathrm{c}} \\
\text { considered }\end{array}$ & & $\mathrm{X}_{\mathrm{c}=0}$ & $\begin{array}{c}\mathrm{X}_{\mathrm{c}} \\
\text { considered }\end{array}$ \\
\hline $\mathrm{Xd}$ & 0.903 & $\leftarrow$ & $\mathrm{Xc}_{\mathrm{c}}$ & 0 & -0.112 \\
\hline $\mathrm{Xd}^{\prime}$ & 0.378 & $\leftarrow$ & $\mathrm{Xad}^{\prime \prime}$ & 0.701 & 0.701 \\
\hline $\mathrm{Xd}^{\prime \prime}$ & 0.288 & $\leftarrow$ & $\mathrm{Xfd}^{\prime}$ & 0.235 & 0.348 \\
\hline $\mathrm{Td}^{\prime}$ & 1.675 & $\leftarrow$ & $\mathrm{Rfd}$ & 0.000745 & 0.000746 \\
\hline $\mathrm{Td}^{\prime \prime}$ & 0.057 & $\leftarrow$ & $\mathrm{Xkd}$ & 0.168 & 0.533 \\
\hline $\mathrm{Ra}$ & 0.00624 & $\leftarrow$ & $\mathrm{Rkd}$ & 0.01461 & 0.03190 \\
\hline $\mathrm{XI}$ & 0.202 & $\leftarrow$ & Tkd & 0.336 & 0.533 \\
\hline \multicolumn{5}{|c}{ Reactance:(pu) Time constant :(sec) }
\end{tabular}

2. $|b|=\left|\frac{x_{2}-x_{d}^{\prime \prime}}{x_{2}+x_{d}^{\prime \prime}}\right| \ll 1$ について

上記が成り立つのは突極同期機では, 各磁極に設けられ た制動巻線が極間接続されている場合である。本解析のモ デル機 48P-15750kVA，6P-400kVA 両機ともこの条件に 該当する。付図 1 に突極同期機の界磁磁極の構造例を示す。

付図 1 の樣に制動巻線を短絡する導体が隣接する磁極と 接続している場合は dq 軸制動巻線漏れリアクタンスの差 が小さく $x_{d}^{\prime \prime} \cong x_{q}^{\prime \prime}$ とすると (付 1$)$ 式の樣になる ${ }^{(7)}$ 。

$$
x_{2}=\frac{1}{2}\left(x_{d}^{\prime \prime}+x_{q}^{\prime \prime}\right) \cong x_{d}^{\prime \prime} \cdot
$$

制動巻線を短絡する導体が隣接する磁極と接続していない 場合は

$$
x_{2}^{\prime \prime} \neq x_{d} .
$$

であり，この場合は $(16)$ 式は

$$
i_{f 1 \text { phase } A C}=\frac{x_{k d}}{x_{f d}+x_{k d}} \frac{x_{d}-x_{d}^{\prime \prime}}{x_{d}^{\prime \prime}+x_{2}} \frac{2 x_{2}}{x_{d}+x_{2}} \cos 2 \theta \times i_{f o}
$$

と若干複雑になる。ここで $(17)$ 式を

$$
K_{1 A C}=\frac{x_{k d}}{x_{f d}+x_{k d}} \frac{x_{d}-x_{d}^{\prime \prime}}{x_{d}^{\prime \prime}+x_{2}} \frac{2 x_{2}}{x_{d}+x_{2}} .
$$

と置き換える。(2) (6) 式と (付 4) 式を連立させて解く事 により，界磁相互漏れリアクタンス $x_{c}$ を含む全リアクタン スと抵抗を算定する事ができる。

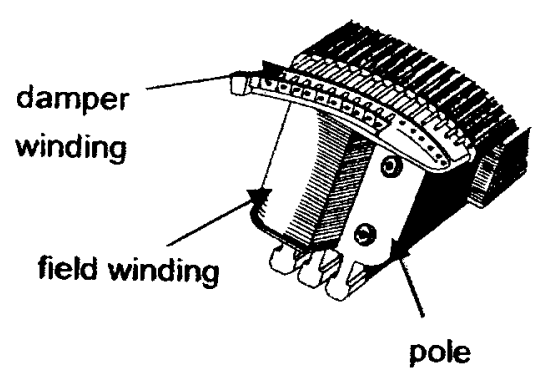

付図 1 突極機界磁磁極構造

app. Fig. 1. Construction of salient pole. 
平 松 大 典 (正員) 1980 年 3 月慶応義塾大学大学院工学研 究科電気工学専攻修士課程修了。同年 4 月 (株) 東芝入社。主として同期発電機 , 同期電動機の設 計に従事。現在 , 電動回転機部参事。技術士 (電 気・電子部門)。

小 柳

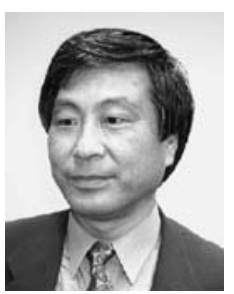

薰 (正員) 1971 年, 東京教育大学理学部応用物理学科 卒。2000 年, 東京都立大学工学研究科電気工学専 攻 (博士課程) 卒。工学博士。英国技術士。1971 年 4 月から 1996 年 3 月まで (株) 東芝にて電力 系統解析に従事。現在 , (株) テプコシステムズに て電力系統分野のソフトウェア開発に従事。1995 年電気学会論文賞受賞。IEE 及び IEEE 会員。

平 山 開一郎 (正員) 1970 年 3 月北海道大学電気工学科卒業。

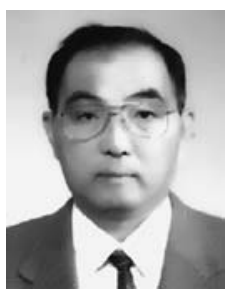
同年 4 月 (株) 東芝入社。主として発電制御シス テムの開発, 設計に従事。現在 , 府中電カシステ 厶工場技監。1994 年計測自動制御学会より技術 賞受賞。工学博士 (北海道大学)。

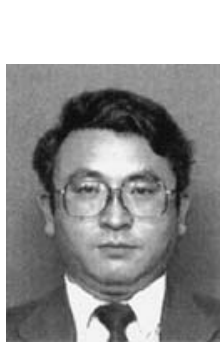

(正員) 1977 年 3 月北海道大学大学院工学研究 科電気工学専攻修士課程修了。同年 4 月 (株) 東 芝入社。重電技術研究所にて主として電力系統の 解析に従事。現在 , 火力水力事業部にて電機系解 析に従事。
徳 増

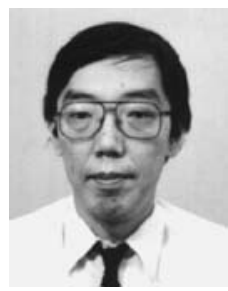

高 畠 幹 生

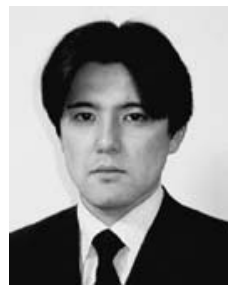

佐 藤 利 幸

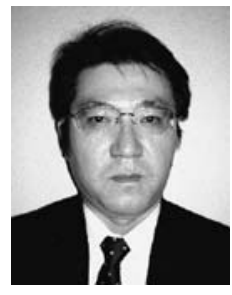

荒

隆 裕

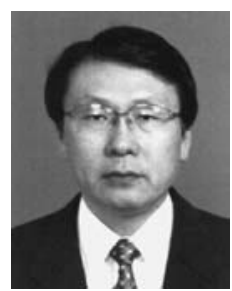

正 (正員) 1974 年 3 月東京大学物理工学科卒業。 同年 4 月 (株) 東芝入社。重電技術研究所にて主 として有限要素法による回転機の電磁界解析に従 事。現在，電力・産業システム技術開発センター 回転機器開発部主査。

(正員) 1997 年 3 月東京大学大学院工学研究科 電気工学専攻修士課程修了。同年 4 月 (株) 東芝 入社重電技術研究所にて主として回転機の電磁界 解析に従事。現在 , 電動機の設計に従事。電動回 転機部主務。
(非会員) 1982 年 3 月宮城工業高等専門学校電気 工学科卒業。同年 4 月北芝電機 (株) 入社。主と して発電機の設計に従事。現在，回転機部参事。 